\title{
The Effects of Climatically Altered Fire REGIMES ON INITIAL SUCCESSIONAL RESPONSES IN Yellowstone National PaRK
}

\author{
$\gamma$ \\ TANIA SCHOENNAGEL $\uparrow$ MONICA G. TURNER \\ DEPARTMENT OF ZOOLOGY \\ UNIVERSITY OF WISCONSIN + MADISON
}

\begin{abstract}
$\downarrow$ INTRODUCTION
Many scientists predict that due to the quick response of fire regimes to changes in climate (Flannigan et al. 1998; Stocks et al. 1998), the most rapid and extensive effects of climate change will be mediated by altered disturbance regimes (Davis and Botkin 1985; Franklin et al. 1992; Graham et al. 1990; Weber and Flannigan 1997). Under climate scenarios expected for $\mathrm{CO}_{2}$ doubling, Price and Rind (1994) predict a $44 \%$ increase in lightning-caused fires and a $78 \%$ increase in total area burned for the U.S.. Although regional climate scenarios are still subject to a fairly high degree of uncertainty, regional predictions for Yellowstone National Park (YNP) estimate an increase in aridity (Balling et al. 1992) and mean July temperatures (Bartlein et al. 1997), suggesting that fire frequencies could significantly increase in YNP over the next century.
\end{abstract}

While several models have simulated the response of western coniferous forests to altered fire regimes (Baker et al. 1991; Gardner et al. 1996; Keane et al. 1990; Keane et al. 1995; Romme and Turner 1991), little empirical work on the successional responses to different intervals of standreplacing fire has been incorporated, and remains a critical element in predicting the effects of climatically altered disturbance regimes in forested landscapes. Previous work in Yellowstone has considered the effects of fire severity, fire size and level of serotiny in explaining initial pathways of postfire succession across the Yellowstone landscape
(Turner et al. 1994; Turner et al. 1997). The effects of the third component of the disturbance regime, fire interval, remains largely unexplored, and represents a fundamental link in predicting potential effects of climate change on the Yellowstone landscape.

The specific objectives of our research, therefore, were to assess: Are there a significantly different successional responses following different intervals of stand-replacing fire in Yellowstone National Park? Because serotiny exerts a strong influence on initial post-fire succession in Yellowstone (characterized by variation in lodgepole pine densities), we also sought to track stand-level changes in serotiny over time. In order to flesh out a possible mechanism for why postfire succession may vary depending upon the age at which the stand burns we asked: What is the temporal variation in lodgepole pine serotiny within the park?

\section{MethoDS}

Yellowstone provides an excellent laboratory for examining the effects of fire regimes on successional patterns. The large-scale fires of 1988 coupled with park records of historical fires, allowed us to compare sites that all burned in 1988, but vary in terms of when they burned prior to 1988 , providing a useful sampling design for testing the effects of fire interval on initial post-fire succession. Using historical fire maps and park-wide aerial 
photos (1:30000), we mapped overlays of historic fires with the 1988 fires onto topographic maps (1:24000), to identify and delineate plots of known fire interval. Next to each plot of known fire interval, we sampled an adjacent plot of unknown fire interval, where the fire previous to 1988 occurred earlier than park records, allowing us to extend the range of fire intervals sampled beyond that covered by park records. We cored 6 of the largest trees in each plot to confirm or estimate the length of the fire interval. Pairing plots allowed us to reduced environmental variation across plots, to better reveal the effect of fire interval on successional patterns.

In each plot, we recorded sapling densities by species in four $2 \mathrm{~m} \times 50 \mathrm{~m}$ belt transects. We also sampled the diversity and abundance of understory species (shrubs, forbs, grasses) by estimating percent cover by species within forty $1 / 4 \mathrm{~m}^{2}$ quadrats along the four transects. Adjacent to these fire interval plots, yet outside the 1988 burn perimeter, we sampled percent serotiny in unburned stands that originated from the fire previous to the 1988 fire, to estimate percent serotiny present in the fire interval plots when burned in 1988. Location of these serotiny plots was also based on the mapping process described above, with ages confirmed by coring. Percent serotiny was estimated in these adjacent unburned areas, by scoring 20 trees within each of three $10 \mathrm{~m}$ radius circles for the presence of serotinous cones (see (Tinker et al. 1994 for details). We sampled a total of 50 fire interval plots ( 25 pairs) for sapling densities, and 50 unburned plots to estimate stand-level percent serotiny and to chart how this varies with stand age.

\section{$\downarrow \quad$ RESULTS AND DISCUSSION}

Postfire successional patterns on the high, infertile subalpine plateaus in Yellowstone are largely characterized by variation in lodgepole pine (PICO) densities. We found significant differences in lodgepole pine densities between paired fire interval plots (paried t-test, $\mathrm{p}$-value $=0.009$ ). When we unpaired the data, we also found significant differences among plots grouped by fire interval, with very short intervals (7-50 yrs) resulting in the lowest densities, and moderate fire intervals (51-160 years) resulting in the highest mean densities of all three groups (Figure 1), suggesting nonlinear successional responses across the broad range of fire intervals sampled (7-395 years).

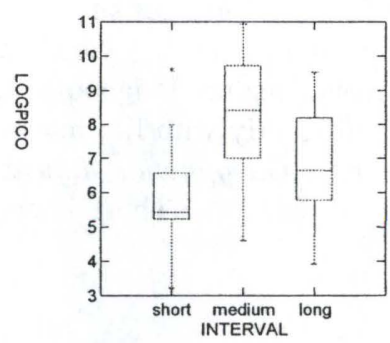

Figure 1. Differences in Lodgepole pine densities (LOGPICO) following different intervals between stand replacing fires. Fire Intervals: Short : 7-50 yrs, $n=20$; Medium: 51-160 yrs, $\mathrm{n}=15$; Long: $161-395$ yrs, $\mathrm{n}=15$.

Levels of serotiny within the pre-fire stand have been shown to be significant in predicting postfire lodgepole seedling densities in Yellowstone (Turner et al 1997). Serotiny is a variable condition in inland lodgepole pines (Pinus contorta var. latifolia), which dominate the subalpine plateau of YNP. Serotinous individuals produce cones that remain closed at maturity, and only when heated by fire do the cones open, releasing numerous seeds onto newly exposed mineral soil. Although serotiny is known to vary spatially across the Yellowstone landscape, our research reveals that in areas where serotiny is present, significant differences in percent serotiny are correlated with stand age (Figure 2). Such temporal variation in serotiny strongly influences postfire lodgepole pine densities following fires of different interval.

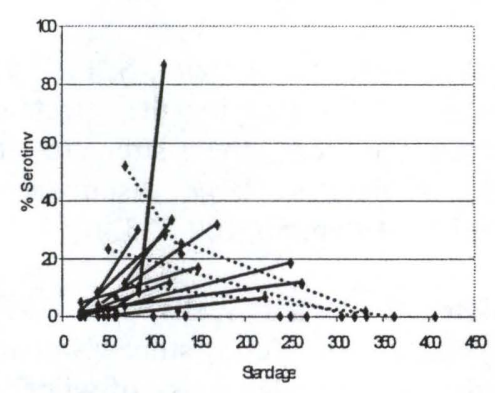

Figure 2. Differences in percent serotiny between paired unburned stands. Lines connect levels of serotiny between two stand of different age at one geographic location. Solid lines connect 12 paired sites that exhibited increased serotiny with stand age. Dashed lines represent 4 paired sites that exhibited decreased serotiny with stand age. 9 sites exhibited no change in serotiny $(<4$ percentage points difference in serotiny).

Total cover and species richness for understory species showed no significant differences between paired plots or across the range of fire intervals sampled, however, some individual groups or particular species exhibited significant trends. For example, shrubs were significantly higher following 
long fire intervals, while forbs and grasses showed no trend. Vaccinium sp. and Heiracium sp., which are common in the understories of mature lodgepole pine forests, also increased significantly with fire interval. Opportunistic species such as Gayophytum diffusum, however, were highest following the short interval burns.

\section{$\downarrow \quad$ SUMMARY AND FURTHER WORK}

Overall, our results indicate that the pattern of initial succession in Yellowstone National Park is contingent on variation in both the spatial and temporal patterns of fire regimes. Serotiny strongly influences successional responses to fire interval and may in fact have been shaped by the spatial and temporal character of past fire regimes. We are currently trying to link fire history to patterns of serotiny in the park.

Although we cannot predict how climate will change in Yellowstone over the next century, understanding successional responses to a range of fire intervals will provide a framework for understanding how the system may respond to potential alterations in the temporal component of the disturbance regime. Based on the empirical work described here, we plan to address this question in detail within a modeling environment.

\section{Literature Cited}

Baker, W. L., Egbert, S. L., and Frazier, S. L. 1991. A spatial model for studying the effects of climate change on the structure of landscapes subject to large disturbances. Ecological Modeling, 56, 109-125.

Balling, R. C., Meter, G. A., and Wells, S. G. 1992. Climate change in Yellowstone National Park: is the drought-related risk of wildfires increasing? Climatic Change, 22, 35-45.

Bartlein, P. J., Whitlock, C., and Shafer, S. L. 1997. Future climate in the Y ellowstone National Park region and its potential impact on vegetation. Conservation Biology, 11(3), 782-792.

Davis, M. B., and Botkin, D. B. 1985. Sensitivity of cool-temperature forests and their fossil pollen record to rapid temperature change. Quat. Research, 23, 327-340.
Flannigan, M. D., Bergeron, Y., Engelmark, O., and Wotton, B. M. 1998. Future wildfire in circumboreal forests in relation to global warming. Journal of Vegetation Science, 9, 469-476.

Franklin, J. F., Swanson, F. J., Harmon, M. E., Perry, D. A., Spies, T. A., Dale, V. H., McKee, A., Ferrell, W. K., Means, J. E., Gregory, S. V., Latin, J. D., Schowalter, T. D., and D.Larson. 1992. Effects of global climatic change on forests in Northwestern North America. In Global warming and biological diversity, R. L. Peters and T. E. Lovejoy, eds., Yale University Press, New Haven, 244-257.

Gardner, R. H., Hargrove, W. W., Turner, M. G., and Romme, W. H. 1996. Climate change, disturbances and landscape dynamics. In Global change and terrestrial ecosystems, B. Walker and W. Steffen, eds., Cambridge University Press, Cambridge, U.K., 149172.

Graham, R. L., Turner, M. G., and Dale, V. H. 1990. How increasing $\mathrm{CO}_{2}$ and climate change affect forests. Bioscience, 40(8), 575-567.

Keane, R. E., Arno, S. F., and Brown, J. K. 1990. Simulating cumulative fire effects in ponderosa pine/Douglas-fir forests. Ecology, 71(1), 189-203.

Keane, R. E., Ryan, K., and Running, S. W. 1995. Simulating the effects of fire and climate change on northern Rocky Mountain landscapes using the ecological process model FIRE-BGC. Interior West Global Change Workshop, Fort Collins, Colorado, 39-47.

Romme, W. H., and Turner, M. G. 1991. Implications of global climate change for biogeographic patterns in the Greater Yellowstone Ecosystem. Conservation Biology, 5(3), 373-386.

Stocks, B. J., Fosberg, M. A., and al., e. 1998. Climate change and forest fire potential in Russian and Canadian boreal forests. Climatic Change, 38, 1-13. 
Tinker, D. B., Romme, W. H., Hargrove, W. W., Gardner, R. H., and Turner, M. G. 1994. Landscape-scale heterogeneity in lodgepole pine serotiny. Canadian Journal of Forest Reseach, 24, 897-903.

Turner, M. G., Hargrove, W. H., Gardner, R. H., and Romme, W. H. 1994. Effects of fire on landscape heterogeneity in Yellowstone National Park, Wyoming. Journal of Vegetation Science, 5, 731-742.
Turner, M. G., Romme, W. H., Gardner, R. H., and Hargrove, W. H. 1997. Effects of fire size and pattern on early succession in Yellowstone National Park. Ecological Monographs, 67(4), 411-433.

Weber, M. G., and Flannigan, M. D. 1997. Canadian boreal forest ecosystem structure and function in a changing climate: impact on fire regimes. Envir.Rev, 5, 145-166. 